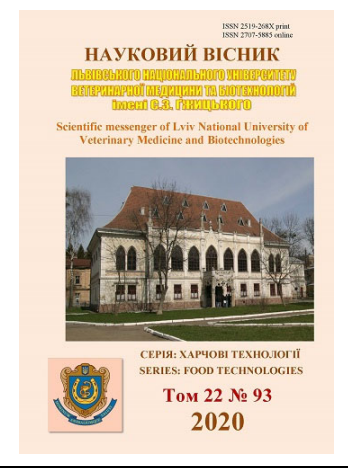

Науковий вісник Дьвівського національного університету ветеринарної медицини та біотехнологій імені С.3. Гжицького. Серія: Харчові технології

\author{
Scientific Messenger of Lviv National University \\ of Veterinary Medicine and Biotechnologies. \\ Series: Food Technologies
}

UDC 637.5

\title{
The use of the $\beta$-cyclodextrin with iodine in technology of making meatballs and their functional characteristics
}

\author{
V. Pasichnyi, A. Ukrainets, Kh. Chebanenko, I. Kamlay \\ National University of Food Technologies, Kyiv, Ukraine
}

Article info

Received 29.01.2020

Received in revised form 28.02.2020

Accepted 02.03.2020

National University of Food Technologies, Volodymyrska Str., 68, Kyiv, 01033, Ukraine. Tel.: +38-066-996-46-94 Email: hristinaom@gmail.com
Pasichnyi, V., Ukrainets, A., Chebanenko, Kh., \& Kamlay, I. (2020). The use of the $\beta$-cyclodextrin with iodine in technology of making meatballs and their functional characteristics. Scientific Messenger of Lviv National University of Veterinary Medicine and Biotechnologies. Series: Food Technologies, 22(93), 45-49. doi: 10.32718/nvlvet-f9308

The pressing issue today is to increase the range of foods that would have increased nutritional value. Therefore, the subject of the study is meatballs cooked on the basis of the thighs of broiler chickens, halffat pork and beef of the first grade. The aim was to create a complete product with high organoleptic characteristics, balanced by biological and nutritional value and to find the optimal concentration of $\beta$ cyclodextrin complex with iodine. The article presents a comparative study of functional and technological characteristics of minced meat based on meat of chicken broilers, pork semifinished and first grade beef. According to the research plan, recipe samples were developed that differed in the type of used raw meat materials and complex of iodine with $\beta$-cyclodextrin content. The processing of products was carried out by the standard method. Among the examined parameters are selected: the content of moisture, water holding and water retaining capacity, $\mathrm{pH}$, fat content. All measurements were examined after preparation and 30 days of storage. All test specimens had a characteristic $p H$ level according to the type of raw material. The moisture content was characteristic of the raw material used and reached the maximum value for sample 8 after preparation $-46.1 \%$, and the minimum for sample $2-38.3 \%$. The moisture content of all samples depends on the consistency of the product. Thus, it has the lowest values among the samples for all samples it includes in its recipe a fillet of broiler chickens, which is more sensitive to heat treatment than the raw material used in other specimens. The results of the determination of fat content in the test specimens completely correspond to the average values for this type of raw material. The highest values were obtained in the samples containing pork, the lowest - the red meat of broiler chickens. Improved recipe for meatballs in tomato sauce with the content of the resulting complex $\beta$-cyclodextrin with iodine of $4 \mu \mathrm{g} / \mathrm{g}$ of product. The complex has absence of negative impact on the quality of the finished product, no impact on quality or sensory characteristics, on functional and technological characteristics and shelf life of the finished product. The results show that the substitution of beef in the recipe for broiler chickens allows the production of meatballs with high quality properties.

Key words: nutrition, iodine deficiency, meat of chicken broilers, functional and technological characteristics, shelf life.

\section{Використання $\beta$-циклодекстрину 3 йодом у технології приготування фрикадельок та їх функціональні характеристики}

\author{
В. М. Пасічний, А. І. Українець, Х. В. Чебаненко, І. С. Камлай
}

Національний університет харчових технологій, м. Київ, Україна

\footnotetext{
Актуальним питанням сьогодення є збільшення асортименту продуктів харчування, які б мали підвищену харчову цінність. Тому предметом досліджень є фрикадельки, приготовані на основі м'яса стегна курчат-бройлерів, свинини напівжсиної та яловичини першого сорту. Метою було створення повноцінного продукту з високими органолептичними показниками, збалансованими за біологічною і харчовою иінністю та підібрати оптимальну концентрацію комплексу $\beta$-циклодекстрину з йодом. $У$ статті наведено порівняльне дослідження функціонально-технологічних показників фаршевих систем на основі м'яса стегна курчатбройлерів, свинини напівжирної та яловичини першого сорту для приготування фрикадельок. Згідно з планом дослідження було
} 
удосконалено рецептури зразків, щчо відрізнялися видом м'ясної сировини, яка використовувалася, та наявністю комплексу $\beta$ циклодекстрину з йодом. Обробку продуктів проводили стандартним методом. Серед досліджуваних показників оброблено значення $\mathrm{pH}$, вмісту вологи, вологозв 'язувальної здатності та вмісту жиру. Показники вимірювали після приготування та зберігання протягом 30 діб. Усі дослідні зразки мали характерний рівень рН відповідно до виду м'ясної сировини. Значення вмісту вологи було характерним для використовуваної сировини та досягало максимального значення для зразка 8 після приготування - 46, 1 \%, а мінімуму - для зразка 2 - 38,3\%. Вологозв'язувальна здатність усіх зразків перебувала в залежності з консистенцією продукту. Вона має найнижчі значення серед дослідних зразків, які включають в свою рецептуру філе курчат-бройлерів, яке є чутливішим до термічної обробки, ніж сировина, щуо використовувалася в інших зразках. Результати визначення вміст жиру у зразках абсолютно відповідають середнім значеннями для даного виду сировини. Найвищі значення отримано у зразках, які містили свинину, найнижчі, які містили червоне м'ясо курчат-бройлерів. Удосконалено рецептуру м'ясних тефтелей у томатному соусі з умістом отриманого комплексу $\beta$-цииклодекстрину з йодом у кількості 4 мкг/2 продукту. Отриманий комплекс характеризується відсутністю негативного впливу на якість готової продукиї, не впливає на органолептичні властивості, функиіонально-технологічні характеристики та термін зберігання готових виробів. Отримані результати засвідчують, щуо заміна яловичини в рецептурі на м'ясо курчат-бройлерів дозволяє виробляти фрикадельки з високими якісними показниками.

Ключові слова: харчування, йододефіцит, м'ясо курчат-бройлерів, функціонально-технологічні показники, термін зберігання.

\section{Вступ}

Чинників, що визначають стан здоров’я населення, $\epsilon$ досить багато, але перебільшити вплив харчування неможливо. Саме харчування є ключовим фактором, що може вплинути як на погіршення власного здоров'я, так і на його поліпшення (Currin et al., 2015). Раціональне харчування необхідне для підтримання повноцінного функціонування здорового організму, воно сприяє профілактиці захворювань і підвищує здатність організму протистояти дії негативних факторів навколишнього середовища, створює умови для фізичного та розумового розвитку і забезпечує високу працездатність (Huda et al., 2011; Bekhit et al., 2014).

Останнім часом спостерігається різке збільшення чисельності хронічних захворювань у населення України, що значною мірою пов'язано 3 порушенням якості харчування. Так, до раціону в значній кількості входять висококалорійні продукти промислового виробництва, тимчасом як дефіцитним є споживання макро- і мікроелементів, повноцінного за якістю білка та інших біологічно активних речовин (Pasichnyj, 2004).

Хвороби, пов'язані з дефіцитом ряду есенційних мікроелементів в раціоні харчування людини поширені у світі, зокрема і в Україні. Понад 2 млрд людей на планеті страждає від недостатньої кількості йоду, 3 них - 285 млн учнів (36,4% від загальної їх кількості) (Omel'chenko et al., 2017). Згідно з даними Міністерства охорони здоров'я, 80 \% українських дітей мають ризик виникнення йододефіциту. Щорічно народжується близько 300 тис. дітей, незахищених від захворювань, викликаних дефіцитом йоду (Malya et al., 2018). Недостатнє споживання цього мікроелемента викликає ендемічний зоб, кретинізм, розлади обміну речовин, імунної системи тощо (Sun et al., 2014). Проблема здорового харчування повинна вирішуватися підприємствами харчової промисловості шляхом створення продуктів підвищеної біологічної цінності як для роздрібної торгівлі, так і для мережі закладів громадського харчування (Mesko et al., 2010). Одним iз можливих шляхів вирішення проблеми дефіциту мікроелементів у харчуванні може стати застосування сполук з корисними властивостями.

Синтезований комплекс $\beta$-циклодекстрину з йодом має здатність поліпшувати йодний статус в організмі людини при вживанні збагачених ним варених ковбасних виробів (Hetzel, 1983). Для розширення асорти- менту продукції та дослідження їхніх властивостей було виготовлено фрикадельки з різних видів м'яса 3 додаванням i без додавання комплексу $\beta$ циклодекстрину 3 йодом та проведено їх фізикохімічні дослідження.

Відсутність досліджень щодо впливу цього комплексу $\beta$-циклодекстрину з йодом на функціональнотехнологічні властивості різних харчових продуктів дають підстави для більш повного вивчення використання таких речовин функціонального призначення 3 метою отримання м'ясного виробу підвищеної харчової та біологічної цінності 3 високими споживчими властивостями.

Метою дослідження є розкриття потенціалу використання нової комплексної сполуки циклодекстрину 3 інкапсулюванням йоду під час виробництва м'ясних фрикадельок, дослідження іiї впливу на фізико-хімічні властивості та оцінка їх товарознавчих властивостей.

Щоб досягти поставленої мети, було визначено такі завдання:

- дослідити зміни функціонально-технологічних показників фаршевих систем для фрикадельок на основі різних видів м'ясної сировини, а саме червоного м'яса курчат-бройлерів, свинини напівжирної, яловичини першого сорту при додаванні комплексу $\beta$ циклодекстрину з йодом.

- дослідити зміни функціонально-технологічних показників готового продукту впродовж терміну придатності.

- визначити раціональний вид м'ясної сировини, який би найкращим чином підійшов для приготування м'ясних фрикадельок 3 додаванням комплексу $\beta$ циклодекстрину з йодом.

\section{Матеріал і методи досліджень}

За планом експерименту було розроблено 5 рецептур зразків (варіанти № 1-5) фаршевих систем зі свининою нежирною, яловичиною першого сорту, стегновою частиною м'яса курчат-бройлерів без додавання комплексу $\beta$-циклодекстрину з йодом і 5 рецептур 3 додаванням комплексу (варіанти № 6-10). Рецептури всіх зразків відрізнялася від класичної типом м'яса, кількістю хліба, наявністю або відсутністю сухої сироватки та білкового стабілізатора (Mogil'nyj \& Tutel'jan, 2012). Загальна характеристика складу фаршевих систем подана у табл. 1 . 
Таблиця 1

Загальний склад фаршевих систем

\begin{tabular}{cc}
\hline № зразка & Основа фаршів \\
\hline 1,6 & Курятина (контроль) \\
2,7 & Свинина $+10 \%$ хліба \\
3,8 & Яловичина $+10 \%$ хліба \\
4,9 & Курятина $+15 \%$ хліба \\
5,9 & Курятина $+20 \%$ хліба \\
\hline
\end{tabular}

Для всіх зразків м'ясо двічі пропускали через м’ясорубку, хліб розмочували у воді, додавали дрібно нарізану або перемелену цибулю, білковий стабіліза- тор або суху молочну сироватку, сіль та комплекс $\beta$ циклодекстрину з йодом згідно з рецептурою.

3 метою забезпечення максимально рівномірного розподілення комплексу у харчовій матриці комплекс попередньо розчиняли у тій кількості води, яка передбачена рецептурою. Всі компоненти перемішують і формують фрикадельки у вигляді кульок масою 25 грам кожна. Кульки перекладають у пароварку i готують на пару 20-25 хвилин або опускають в окріп, під кришкою варять 15-20 хвилин до готовності. Рецептурний склад всіх модельних фаршів м'ясних фрикадельок наведено у табл. 2.

\section{Таблиця 2}

Рецептурний склад модельних фаршів м'ясних фрикадельок

\begin{tabular}{|c|c|c|c|c|c|c|c|c|c|c|}
\hline Найменування сировини за варіантом & № 1 & № 2 & № 3 & № 4 & № 5 & № 6 & № 7 & № 8 & № 9 & № 10 \\
\hline Червоне м'ясо курчат-бройлерів & 65 & - & - & 60 & 50 & 65 & - & - & 60 & 50 \\
\hline Свинина нежирна & - & 65 & - & - & - & - & 55 & - & - & - \\
\hline Яловичина I сорту & - & - & 65 & - & - & - & - & 55 & - & - \\
\hline Білковий стабілізатор (БС) & 4 & - & - & - & - & 4 & - & - & - & - \\
\hline Хліб & 10 & 10 & 10 & 15 & 20 & 10 & 10 & 10 & 15 & 20 \\
\hline Цибуля & 5 & 5 & 5 & 5 & 5 & 5 & 5 & 5 & 5 & 5 \\
\hline Суха сироватка & - & 4 & 4 & 4 & 4 & - & 4 & 4 & 4 & 4 \\
\hline Сіль & 1 & 1 & 1 & 1 & 1 & 1 & 1 & 1 & 1 & 1 \\
\hline Вода & 15 & 15 & 15 & 15 & 20 & 15 & 15 & 15 & 15 & 20 \\
\hline Комплекс $\beta$-циклодекстрину з йодом & & & & & & & & 0,000 & & \\
\hline
\end{tabular}

В кінці процесу приготування для зразків визначали такі функціонально-технологічні показники: значення $\mathrm{pH}$ водної витяжки з м'яса, вміст вологи, вологозв'язувальну здатність (В33), вміст жиру.

Вміст вологи вимірювали арбітражним методом висушуванням наважки середньої проби продукту (35 г) за температури $120{ }^{\circ} \mathrm{C}$ протягом $100-120$ хв до постійної маси. Вологозв'язуючу здатність визначали методом пресування (Bozhko et al., 2018). В ході роботи усі показники визначалися протягом доби після термічної обробки зразків та на 30 добу зберігання в замороженому стані.

\section{Результати та їх обговорення}

Усі дослідні зразки мали характерний рівень $\mathrm{pH}$ відповідно до виду м'ясної сировини. У зразках 3 внесенням комплексу $\beta$-циклодекстрину з йодом прослідковувалась стабільність значення $\mathrm{pH}$ порівняно зі зразками, в системі яких був відсутній цей комплекс. Максимальні відхилення значення $\mathrm{pH}$ зафіксовані для зразків 3 та 8 на основі яловичини. Однак загалом при використанні комплексу суттєвих змін $\mathrm{pH}$ не спостерігалось.

У табл. 3 наведено основні фізико-хімічні та функціонально-технологічні показники фрикадельок без та 3 додаванням комплексу $\beta$-циклодекстрину 3 йодом у досліджуваних зразках.

Таблиця 3

Основні показники дослідних зразків

\begin{tabular}{|c|c|c|c|c|c|c|c|}
\hline \multirow{2}{*}{$\begin{array}{c}\text { Показники } \\
\text { за варіантами } \\
\text { Термін зберігання }\end{array}$} & \multicolumn{2}{|c|}{$\mathrm{pH}$} & \multicolumn{2}{|c|}{$\begin{array}{c}\text { Вміст вологи, } \\
\% \\
\end{array}$} & \multicolumn{2}{|c|}{ B33a, \% } & \multirow{2}{*}{$\frac{\text { Вміст жиру, \% }}{1 \text { доба }}$} \\
\hline & 1 доба & 30 доба & 1 доба & 30 доба & 1 доба & 30 доба & \\
\hline Зразок № 1 & 6,85 & 6,93 & 37,4 & 37,5 & 64,40 & 62,20 & 9,43 \\
\hline Зразок № 2 & 6,70 & 6,89 & 38,3 & 38,4 & 71,20 & 69,35 & 28,20 \\
\hline Зразок № 3 & 6,10 & 6,50 & 46,1 & 46,2 & 77,10 & 75,35 & 17,60 \\
\hline Зразок № 4 & 6,70 & 6,94 & 41,4 & 41,5 & 65,37 & 63,10 & 9,43 \\
\hline Зразок № 5 & 6,73 & 6,94 & 44,2 & 44,3 & 65,90 & 63,40 & 9,43 \\
\hline Зразок № 6 & 6,86 & 6,93 & 37,4 & 37,5 & 64,40 & 62,40 & 9,43 \\
\hline Зразок № 7 & 6,70 & 6,89 & 38,3 & 38,4 & 71,20 & 69,30 & 28,20 \\
\hline Зразок № 8 & 6,10 & 6,50 & 46,1 & 46,2 & 77,15 & 75,10 & 17,60 \\
\hline Зразок № 9 & 6,71 & 6,94 & 41,2 & 41,5 & 65,38 & 63,25 & 9,43 \\
\hline Зразок № 10 & 6,74 & 6,94 & 44,3 & 44,3 & 65,90 & 63,50 & 9,43 \\
\hline
\end{tabular}


Вміст вологи в усіх зразках м'ясного фаршу перебував у межах 37-46 \% і залежав насамперед від виду м'ясної сировини. Максимальне значення вмісту вологи зафіксовано у зразках 3 та 8 (46,2 \%), що є дещо нижче норми за середніми значеннями для даного виду сировини (60-68 \%) (Zheng, 2006). Мінімальне у зразках 1 та $6(37,5 \%)$. Вміст вологи суттєво не змінювався при додаванні комплексу, незалежно від виду сировини. В усіх зразках показник вмісту вологи не зазнав значних змін протягом зберігання, тому можна зробити висновок про те, що відмінності у значеннях цього показника для різних видів сировини обумовлені фізико-хімічними особливостями вхідної сировини.

Вологозв'язувальна здатність має найнижчі значення серед дослідних зразків, до рецептури яких включено філе курчат-бройлерів, яке $є$ більш чутливим до термічної обробки, ніж сировина, що використовувалась у інших зразках. Максимальне значення В33 зафіксовано у зразку 3 та 8. Варто зазначити, що значення В33 не зазнали відчутного зниження для усіх зразків протягом терміну зберігання, різниця між показником після 30 діб зберігання досягала 3 \%. Це може свідчити про низький рівень денатурації білків основної сировини. Сам комплекс $\beta$-циклодекстрину 3 йодом негативного впливу на вологозв'язувальну здатність, як бачимо 3 результатів дослідження, не дає.

Результати визначення вміст жиру у досліджуваних зразках повністю відповідають середнім значенням для даного виду сировини. Найвищі значення отримано у зразках, які містили свинину, найнижчі червоне м'ясо курчат-бройлерів.

На рис. 1 показано вихід фрикадельок після термічної обробки, виготовлених з додаванням та без додавання комплексу $\beta$-циклодекстрину з йодом.

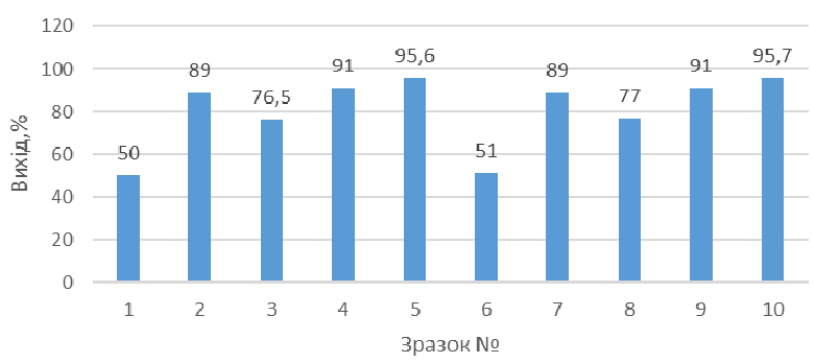

Рис. 1. Вихід фрикадельок

Найвищі значення виходу мають зразки фаршевих систем, які складаються в курятини з додаванням сухої сироватки та 15 або $20 \%$ хліба, замоченого у воді. Вміст добавки комплексу $\beta$-циклодекстрину 3 йодом ніяким чином вихід суттєво не змінює, оскільки кількість іiі для забезпечення достатнього рівня йоду в організмі необхідна зовсім мізерна.

Найгірші показники виходу мали зразки, до фаршевих систем яких входив білковий стабілізатор. Також варто зазначити, що такі зразки характеризувались не притаманною для фрикадельок консистенцією та впродовж приготування втрачали характерну для них форму.
Також проведено оцінку органолептичних показників якості фрикадельок за (Kyshen'ko et al., 2010). Результати цих показників наведено на рис 2. Згідно 3 отриманими результатами органолептичних показників можна впевнено сказати, що внесена добавка цих показників фактично не змінює, тому, якщо орієнтуватись на перші п'ять зразків, найкращі органолептичні показники мають зразки 4 та 5 i відповідно такі ж у зразків 9 та 10. Зразки 1 та 6 не рекомендується обирати для приготування фрикадельок, доцільніше буде використати таку фаршеву систему у виробництві варених ковбасних виробів.
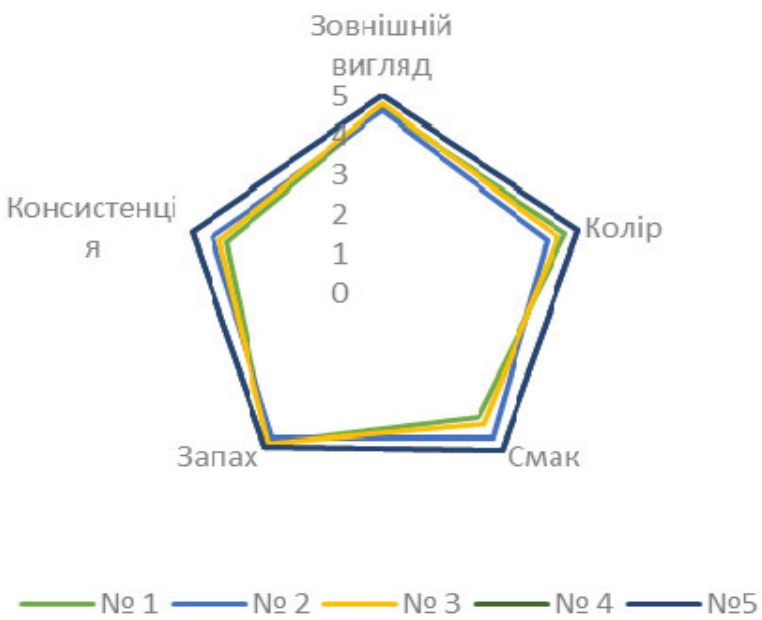

Рис. 2. Органолептичні показники якості фрикадельок

Згідно з отриманими результатами досліджень обрано кращими за їхніми властивостями зразки номер 9 та 10 фрикадельок з додаванням комплексу. Позитивним $є$ той факт, що найкращими згідно 3 дослідженнями виявились зразки рецептур на основі курячого м'яса. Відомо, що куряче м'ясо містить значну кількість фрагментів тирозину, який може вступати в реакцію 3 молекулярним йодом 3 утворенням 3,5дийодтирозину (Polumbryk et al., 2016). Ця сполука $є$ проміжною у синтезі трийодтироніну і тироксину основних гормонів щитоподібної залози (Liu et al., 2015). Тому як найперспективніший об'єкт збагачення обрано фрикадельки з червоним м'ясом курчатбройлерів.

Перспектива залучення як додаткового джерела йоду в м'ясній продукції комплексу $\beta$ циклодекстрину з йодом розкрита у варених ковбасних виробах та досліджується у м'ясних тефтелях 3 додаванням томатного соусу (Polumbryk, 2019). Але оскільки температура термічної обробки варених ковбасних виробів, тефтелей та фрикадельок є різною, дослідження ступеня утримання йоду після термічної обробки має бути предметом подальших досліджень. Температури обробки даних видів продукції дозволяють зберегти необхідні властивості комплексу $\beta$-ЦД$\mathrm{I}_{2}$, оскільки його температура плавлення $72^{\circ} \mathrm{C}$ і розкладається він при $185{ }^{\circ} \mathrm{C}$ при подальшому нагріванні (Rana \& Raghuvanshi, 2013). 


\section{Висновки}

Проведені дослідження доводять, що при використанні в технології приготування фрикадельок необхідно враховувати тип основної м'ясної сировини. Фрикадельки виготовлені з м'яса курчат-бройлерів за розробленими рецептурами 3 використанням сухої молочної сироватки за відсутності білкового стабілізатора, використання якого в складі фрикадельок є нераціональним.

Доведено, що використання комплексу $\beta$ циклодекстрину з йодом у складі рецептур фрикадельок не впливає на фізико-хімічні показники та вихід продукту. Впродовж терміну придатності досліджувані показники змінювалися в межах норми, встановленої для певних видів м'ясної сировини.

Подальші дослідження будуть спрямовані на визначення термічної стабільності йоду в процесі термічної обробки для обгрунтування включення до раціонів споживання розроблених м'ясних продуктів - 3 метою забезпечення добової потреби в йоді.

\section{References}

Bekhit, A. A., Hopkins, D. L., Geesink, G., Bekhit, A. A., \& Franks, P. (2014). Exogenous proteases for meat tenderization. Critical reviews in food science and nutrition, Crit Rev Food Sci Nutr., 54(8), 1012-1031. doi: 10.1080/10408398.2011.623247.

Bozhko, N. V., Tyshhenko, V. I., Pasichnyj, V. M., Jushko, M. I., Zhukova, Ja. F., \& Popova, Je. S. (2018). Study of functional and technological indices of meatcontaining loaf with Muscovy duck meat and white carp. Naukovyj visnyk LNUVMB imeni S.Z. G'zhyc'kogo, 20(85), 19-22. doi: 10.15421/nvlvet8504.

Currin, A., Swainston, N., Day, P. J., \& Kell, D. B. (2015). Synthetic biology for the directed evolution of protein biocatalysts: navigating sequence space intelligently. Chemical Society Reviews, 44(5), 11721239. doi: 10.1039/c4cs00351a.

Hetzel, B. S. (1983). Iodine deficiency disorders (IDD) and their eradication. Lancet, 322, 1126-1129. doi: 10.1016/S0140-6736(83)90636-0.

Huda, N., Putra, A. A., \& Ahmad, R. (2011). Potential Application of Duck Meat for Development of Processed Meat Products. Current Research in Poultry Science, 1, 1-11. doi: 10.3923/crpsaj.2011.1.11.

Kyshen'ko, I. I., Starchova, V. M., \& Goncharov, G. I. (2010). Tehnologija m'jasa ta m'jasoproduktiv. Praktykum: navch. Posibnyk. Nac. un-t harch. Tehnol, Kyiv (in Ukrainian).
Liu, D., Lin, X., \& Yu, F. (2015). Effects of 3,5diiodotyrosine and potassium iodide on thyroid function and oxidative stress in iodine-excess Wistar rats. Biol. Trace Elem. Res, 168, 447-452. doi: 10.1007/s12011-015-0371-y.

Malya, F. U., Kadioglu, H., \& Hasbahceci, M. (2018). The correlation between breast cancer and urinary iodine excretion levels. J. Int. Med. Res, 46(2), 687692. doi: 10.1177/0300060517717535.

Mesko, M., Mello, P., \& Bizzi, C. (2010). Iodine determination in food by inductively coupled plasma mass spectrometry after digestion by microwaveinduced combustion. Anal. Bioanal. Chem, 398, 1125-1131. doi: 10.1007/s00216-010-3766-9.

Mogil'nyj, M. P. \& Tutel'jan, V. A. (2012). Sbornik receptur bljud i kulinarnyh izdelij dlja pitanija detej $\mathrm{v}$ doshkol'nyh obrazovatel'nyh uchrezhdenijah. DeLi print, Moscow (in Russian).

Omel'chenko, H. V., Polumbrik, M. O., \& Pasichnij, V. M. (2017). Kompleks jodu z $\beta$-ciklodekstrinom jak funkcional'na dobavka u tehnologiï varenih kovbasnih virobiv. Naukovi praci Nacional'nogo universitetu harchovih tehnologij, 23(1), 203-209 (in Ukrainian).

Pasichnyj, V. N. (2004). Problema belka yly problema kachestva pyshhy. Mjasnoj byznes, 2(1), 12-18 (in Russian).

Polumbryk, M. O., Kotljar, Je. O., Omel'chenko, H. V., Polumbryk, M. M., \& Pasichnyj, V. M. (2016). Vykorystannja kompleksu $\beta$-cyklodekstrynu z jodom pry vyrobnyctvi varenyh kovbasnyh vyrobiv. Harchova nauka i tehnologija, 10(3), 45-49. doi: 10.15673/fst.v10i3.180.

Polumbryk, M., Kravchenko, V., \& Pasichnyi, V. (2019). The effect of intake of sausages fortified with $\beta-C D-\mathrm{I}_{2}$ complex on iodine status and thyroid function: A preliminary study. Journal of Trace Elements in Medicine and Biology, 51, 159-163. doi: 10.1016/j.jtemb.2018.10.014.

Rana, R., \& Raghuvanshi, R. S. (2013). Effect of different cooking methods on iodine losses. J. Food Sci. Technol., 50, 1212-1216. doi: 10.1007/s13197-011-04367.

Sun, X., Shan, Z., \& Teng, W. (2014). Effects of increased iodine intake on thyroid disorders. Endocrinol. Metab., 29, 240-247. doi: 10.3803/EnM.2014.29.3.240.

Zheng, C., Sun, D. W., \& Zheng, L. (2006). Correlating colour to moisture content of large cooked beef joints by computer vision. Journal of Food Engineering, 77(4), 858-863. doi: 10.1016/j.jfoodeng.2005.08.013. 